Samikannu Rakesh and Muthusamy Sarojadevi

\title{
SYNTHESIS AND CHARACTERIZATION OF CYANATE ESTER AND ITS BLENDS WITH BISPHENOL DICYANATE ESTER
}

\author{
Department of Chemistry, Anna University, Chennai-600 025, India \\ msrde2000@yahoo.com \\ Received: M ay 05, 2008
}

(c) Rakesh S., Sarojadevi M. 2008

\begin{abstract}
A new keto-ene functionalized 1, 5-bis (4-hydroxyphenyl)penta-1,4-dien-3-one (HPDO) was prepared from $p$-hydroxy benzaldehyde and acetone using boric acid as a catalyst. The prepared bisphenol was converted into 1,5-bis (4-cyanatophenyl) penta-1,4-diene3 -one (CPDO) by reacting with cyanogen bromide $(\mathrm{CNBr})$ in the presence of triethylamine. The synthesized bisphenol and the dicyanate ester were characterized by Fourier transform infrared spectroscopy (FT-IR), nuclear magnetic resonance spectroscopy $\left({ }^{1} \mathrm{H}-\mathrm{NMR}\right.$ and ${ }^{13} \mathrm{C}-\mathrm{NMR}$ ) and elemental analysis (EA) techniques. CPDO was then blended with a commercial bisphenol-A dicyanate ester (BADCy) at different ratios (100:0, 75:25, 50:50. 25:75, $0: 100)$ and the cure characteristics were studied. CPDO was found to be cured at a lower temperature than BADCy. The cyanate ester blends were cured at $373 \mathrm{~K}$ (30 min) $\rightarrow$ $423 \mathrm{~K}(30 \mathrm{~min}) \rightarrow 473 \mathrm{~K}(60 \mathrm{~min}) \rightarrow 523 \mathrm{~K}(3 \mathrm{~h})$. Differential scanning calorimetry (DSC) and thermogravimetric analysis (TGA) were used to study the thermal properties. DSC studies show that the cure (peak) temperature of $\mathrm{CPDO}$ with and without a catalyst was found to be $408 \mathrm{~K}$ and $466 \mathrm{~K}$ respectively. The initial degradation temperature of the cured resins was found to be in the range from $701 \mathrm{~K}$ to $705 \mathrm{~K}$. The Limiting Oxygen Index (LOI) value, determined by Van Krevelen's equation, shows that these blends have good flame retardant properties.
\end{abstract}

Key words: cyanate ester, low curing temperature, thermal property.

\section{Introduction}

In recent years increasing 'high-tech' applications make ever-increasing demand for materials in both terrestrial and extra terrestrial environments use. High temperature resistant polymers are in great demand for high-speed aircraft structures and as structural components of space vehicles. Cyanate ester (CE) resin systems are currently attracting increasing attention as high-performance thermosetting resins and they can be used as the matrices for high performance composites because of their superior mechanical properties which are used in the electronic devices, high-temperature adhesive and aerospace industries [1-5]. They have the processability similar to that of epoxy resins and the thermal properties similar to those of phenolic resins. CE resins have their own unique properties such as a good strength, low dielectric constant, radar transparency, low water absorption, and superior metal adhesion $[6,7]$. Curing of cyanate esters is catalyzed by heat or a combination of heat and catalyst [8]. The great difference in processing between epoxies and cyanate esters is that the latter ones need relatively high curing temperature. The high curing temperature causes high energyconsumption but what is more important, the resultant resins and composites tend to have higher stress concentration and internal defects and therefore the properties of the resultant composites decline [9-14]. Hence, preparation of cyanate ester having low cure temperature is chosen as the target of the present work and the properties of the prepared cyanate ester with a commercial BADCy as blends have been investigated.

\section{Experimental}

\subsection{Materials}

Bisphenol A cyanate resin, BADCy, (4,4' dicyanato-2,2-diphenylpropane) monomer with the trade name AroCy B10 (99.5\%) was supplied by $\mathrm{NaBond}$ Technologies co., Limited, (China). The metal complex cobalt (II) naphthenate, Co (nap), and the co-catalyst nonylphenol, NP, (technical grade) were purchased from Aldrich, USA and used as a catalyst. Acetone, $p$-hydroxybenzaldehyde and cyanogen bromide $(\mathrm{CNBr})$ were purchased from SRL, (India). Triethylamine $\left(\mathrm{Et}_{3} \mathrm{~N}\right)$ was purchased from E-Merck (India). Triethylamine and acetone were distilled prior to use.

\subsection{M easurements}

FT-IR (Fourier Transform Infrared Spectroscopy) spectra were obtained using a Perkin Elmer (spectrum-RX1) with a $\mathrm{KBr}$ pellet. ${ }^{1} \mathrm{H}-\mathrm{NMR}$ and ${ }^{13} \mathrm{C}-\mathrm{NMR}$ 
spectra were recorded using a Bruker SF-II spectrometer at an operating frequency of $300 \mathrm{MHz}$. The samples, dissolved in DMSO- $\mathrm{d}_{6}$ were scanned from 0 to $12 \mathrm{ppm}$ using TMS as an internal reference. Elemental analysis was performed on a Vario micro-cube analyzer. Melting points were determined on an electrothermal melting point apparatus IA 6304 using capillary tubes and are uncorrected. DSC studies were carried out using TA instruments Q10 model equipment. DSC was ranged from room temperature to $623 \mathrm{~K}$ at a heating rate of $283 \mathrm{~K} / \mathrm{min}$ in a flowing nitrogen. Thermogravimetric analysis (TGA) was carried out with TA instruments Q600 model machine at a heating rate of $283 \mathrm{~K} / \mathrm{min}$ in $\mathrm{N}_{2}$ atmosphere.

\subsection{Synthesis of 1,5-bis (4-hydroxyphenyl)penta-1,4-dien-3-one (HPDO)}

$20 \mathrm{ml}$ of concentrated hydrochloric acid was added to a mixture of $7.44 \mathrm{~g}(0.061 \mathrm{~mol})$ of $p$-hydroxybenzaldehyde and $3.77 \mathrm{~g}(0.061 \mathrm{~mol})$ of boric acid in a $250 \mathrm{ml}$ round-bottomed flask. The flask was cooled to $273 \mathrm{~K} .2 .3 \mathrm{ml}(0.030 \mathrm{~mol})$ of acetone was added to this mixture dropwise with a vigorous and continued stirring at $273 \mathrm{~K}$ for $48 \mathrm{~h}$. Then the mixture was poured into 11 of cold water. The precipitated product was filtered, washed with distilled water and dried at $343 \mathrm{~K}$ for $24 \mathrm{~h}$. Recrystallization from methanol gave light yellow crystals with more than $90 \%$ yield of the main compound [15]. Melting point (mp) was $438 \mathrm{~K}$. $\mathrm{IR}(\mathrm{KBr}): 3452 \mathrm{~cm}^{-1}\left(v_{\mathrm{OH}}\right)$, $1604 \mathrm{~cm}^{-1}\left(v_{\mathrm{C}=\mathrm{C}}\right), 1650 \mathrm{~cm}^{-1}\left(\mathrm{v}_{\mathrm{C}=\mathrm{O}}\right) .{ }^{1} \mathrm{H}-\mathrm{NMR}\left(\mathrm{CDCl}_{3}\right.$, TMS, ppm): $9.92\left(2 \mathrm{H}, \mathrm{s}, \mathrm{H}_{\mathrm{a}}\right) ; 7.91\left(4 \mathrm{H}, \mathrm{d}, \mathrm{H}_{\mathrm{b}}\right) ; 7.48(4 \mathrm{H}$, $\left.\mathrm{d}, \mathrm{H}_{\mathrm{c}}\right), 7.83\left(2 \mathrm{H}, \mathrm{d}, \mathrm{H}_{\mathrm{d}}\right) ; 7.37\left(2 \mathrm{H}, \mathrm{d}, \mathrm{H}_{\mathrm{e}}\right) \cdot{ }^{13} \mathrm{C}-\mathrm{NMR}$ $\left(\mathrm{CDCl}_{3}, \mathrm{TMS}, \mathrm{ppm}\right): \mathrm{C}_{1}-152.8, \mathrm{C}_{2}-115.9, \mathrm{C}_{3}-130.2, \mathrm{C}_{4}-$ 133.1, $\mathrm{C}_{5}-140.35, \mathrm{C}_{6}-126.2, \mathrm{C}_{7}-188.04$. Elemental analysis: M.F. $\mathrm{C}_{17} \mathrm{H}_{14} \mathrm{O}_{3}$ calculated: C: $76.68, \mathrm{H}: 5.30$, Found: C: 76.52 , H: 5.19

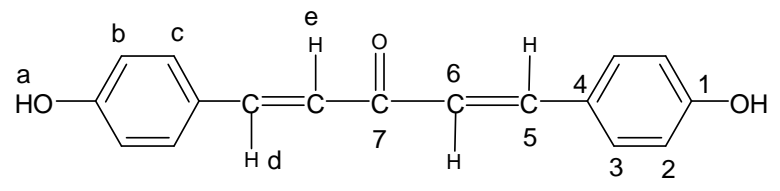

\subsection{Synthesis of 1,5-bis (4-cyanato phenyl) penta-1,4-dien-3-one (CPDO)}

A $250 \mathrm{ml}$ three-necked round bottomed flask equipped with a magnetic stirring device and a nitrogen inlet was loaded with $3.5 \mathrm{~g}(0.0131 \mathrm{~mol})$ of HPDO. The flask was maintained at $258 \mathrm{~K}$ and then $2.7 \mathrm{~g}(0.026 \mathrm{~mol})$ of $\mathrm{CNBr}$ was added while stirring. $3.6 \mathrm{ml}(2 \mathrm{~mol})$ of triethylamine was added to this mixture dropwise with a continuous stirring. After complete addition of triethylamine, the reaction mixture was stirred for a period of $2 \mathrm{~h}$ at the bath temperature of $258 \mathrm{~K}$. The mixture was filtered under vacuum to remove the triethylamine. The filtrate was poured into a cold distilled water to precipitate the cyanate ester from the solution. The precipitate was washed with aqueous hydrochloric acid solution until a neutral one. A light yellow product (yield $87 \%$ ) was obtained. Mp. $444 \mathrm{~K}$. IR (KBr): 2277 and $2238 \mathrm{~cm}^{-1}\left(v_{\mathrm{OCN}}\right)$, $1594 \mathrm{~cm}^{-1}\left(\mathrm{v}_{\mathrm{C}=\mathrm{C}}\right), 1655 \mathrm{~cm}^{-1}\left(\mathrm{v}_{\mathrm{C}=\mathrm{o}}\right)$. ${ }^{1} \mathrm{H}-\mathrm{NMR}\left(\mathrm{CDCl}_{3}\right.$, TMS, ppm): $7.91\left(4 \mathrm{H}, \mathrm{d}, \mathrm{H}_{\mathrm{a}}\right) ; 7.48\left(4 \mathrm{H}, \mathrm{d}, \mathrm{H}_{\mathrm{b}}\right) ; 7.83(2 \mathrm{H}$, $\left.\mathrm{d}, \mathrm{H}_{\mathrm{c}}\right) ; 7.38\left(2 \mathrm{H}, \mathrm{d}, \mathrm{H}_{\mathrm{d}}\right) .{ }^{13} \mathrm{C}-\mathrm{NMR}\left(\mathrm{CDCl}_{3}\right.$ TMS, ppm): $\mathrm{C}_{1}-108.2, \mathrm{C}_{2}-153.4, \mathrm{C}_{3}-116.1, \mathrm{C}_{4}-130.9, \mathrm{C}_{5}-133.7, \mathrm{C}_{6}-$ 140.9, $\left.\mathrm{C}_{7}-126.5, \mathrm{C}_{8}-188.3\right)$. Elemental analysis: M.F. $\mathrm{C}_{19} \mathrm{H}_{12} \mathrm{~N}_{2} \mathrm{O}_{3}$ calculated: $\mathrm{C}: 72.15, \mathrm{H}: 3.82, \mathrm{~N}: 8.82$, Found: C: $72.06, \mathrm{H}: 3.71, \mathrm{~N}: 8.70$.

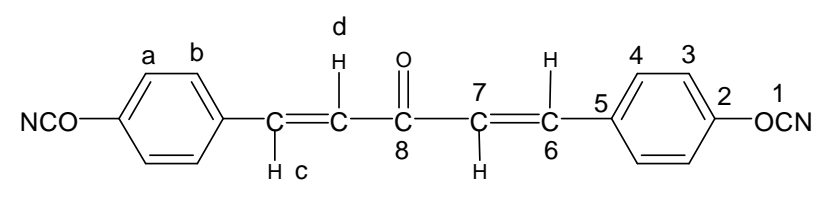

\section{Results and Discussion}

\subsection{Spectral Characterization}

HPDO was prepared from $p$-hydroxybenzaldehyde and acetone in the presence of a boric acid (Scheme 1). HPDO was analyzed by FT-IR. The formation of a new band at $1580 \mathrm{~cm}^{-1}$ corresponds to the alkene group $(\mathrm{C}=\mathrm{C})$. The absence of an aldehydic band at $1725 \mathrm{~cm}^{-1}$ confirms the completion of the reaction. Fig. 1 shows the FT-IR spectrum of HPDO. The dicyanate ester was prepared from its precursor diol and $\mathrm{CNBr}$ in the presence of triethylamine. FT-IR was used to confirm the formation of the cyanate ester group. Fig.2 shows the FT-IR spectrum of CPDO. The bands at 2238 and $2277 \mathrm{~cm}^{-1}$ confirm the presence of $-\mathrm{OCN}$ group. The absorptions due to alkene $(\mathrm{C}=\mathrm{C})$ and keto $(\mathrm{C}=\mathrm{O})$ groups were obtained at 1655 and $1594 \mathrm{~cm}^{-1}$ respectively. The disappearance of $-\mathrm{OH}$ band at $3400-3500 \mathrm{~cm}^{-1}$ proves the completion of the reaction. Fig. 3 shows the FT-IR spectrum of polycyanurate. Trimerization of the cyanate groups can be easily monitored by the disappearance of the band at $2200-2300 \mathrm{~cm}^{-1}$ due to the stretching vibration of $-\mathrm{OCN}$ in the IR spectrum and the appearance of new absorptions at 1594 and $1358 \mathrm{~cm}^{-1}$ for $\mathrm{N}-\mathrm{C}=\mathrm{N}$ and $\mathrm{N}-\mathrm{C}-\mathrm{O}$ stretching vibrations respectively. In the ${ }^{1} \mathrm{H}-\mathrm{NMR}$ spectrum of the dicyanate (Fig. 4) the $\mathrm{CH}=\mathrm{C}$ proton adjacent to aromatic ring appears as the doublet at $7.83 \mathrm{ppm}$ and $\mathrm{C}=\mathrm{CH}$ proton adjacent to carbonyl group appears as the doublet at $7.33 \mathrm{ppm}$. Aromatic protons appear in the range of $7.54-7.98 \mathrm{ppm}$. The absence of hydroxyl protons at 8.5$10 \mathrm{ppm}$ proves the formation of the dicyanates. In the ${ }^{13} \mathrm{C}-\mathrm{NMR}$ (Fig. 5) spectrum the carbon of the cyanate group is found at $108.23 \mathrm{ppm}$. Aromatic carbons appear in the range of $116.1-153.4 \mathrm{ppm}$. The $\mathrm{C}=\mathrm{C}$ carbon signal 


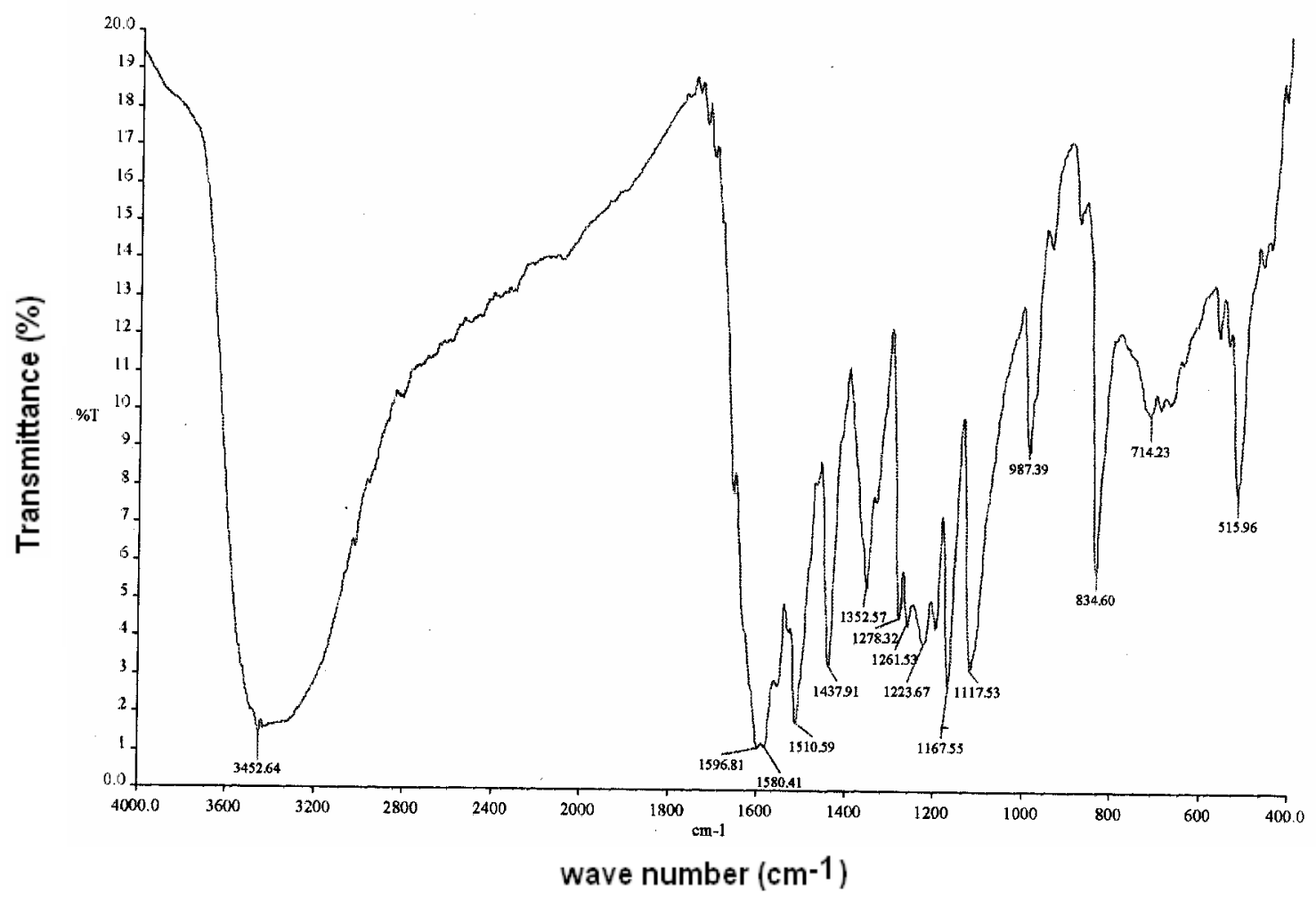

Fig.1. FT-IR spectrum of HPDO

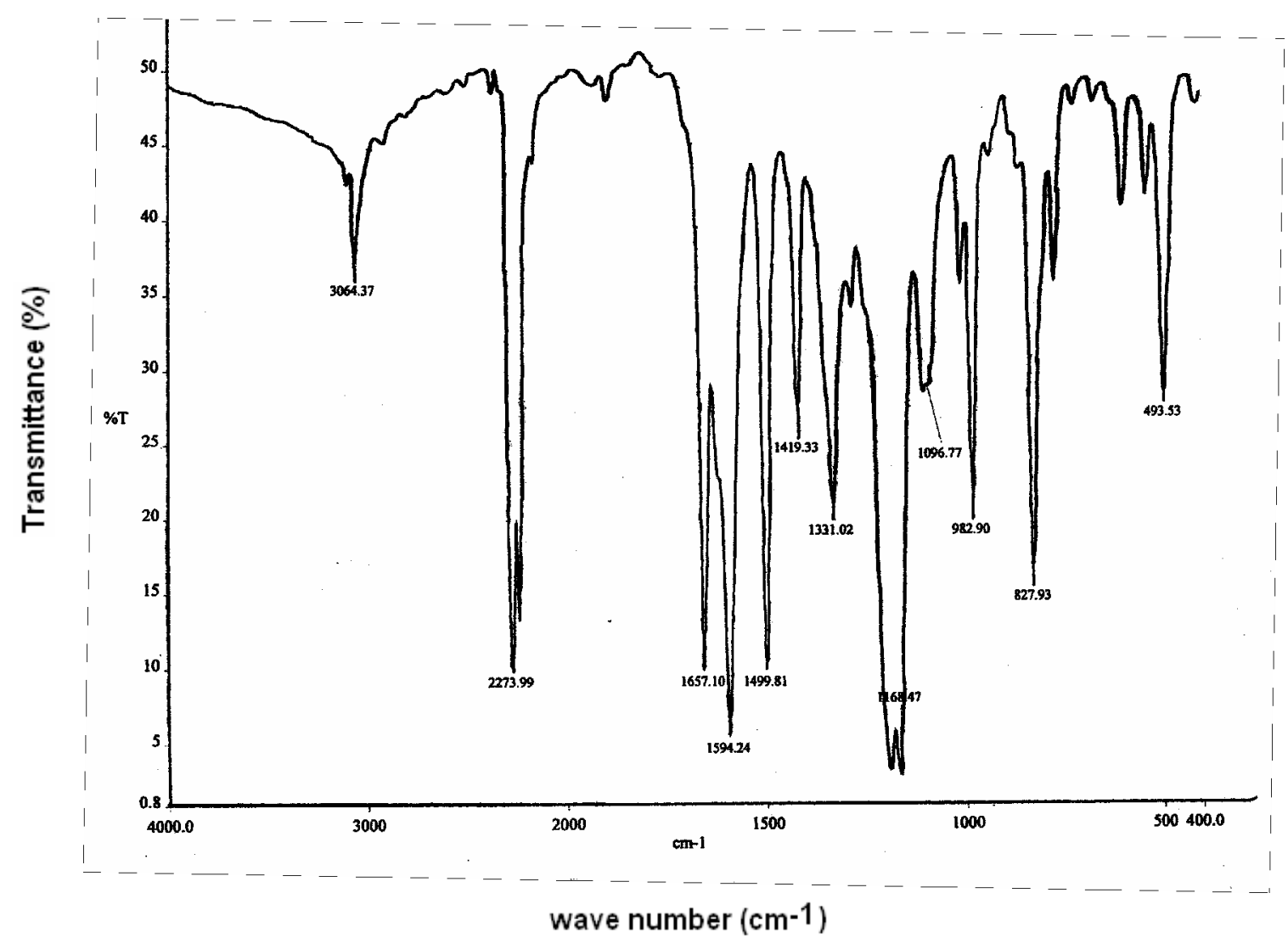

Fig. 2. FT-IR spectrum of CPDO 
Samikannu Rakesh et al.
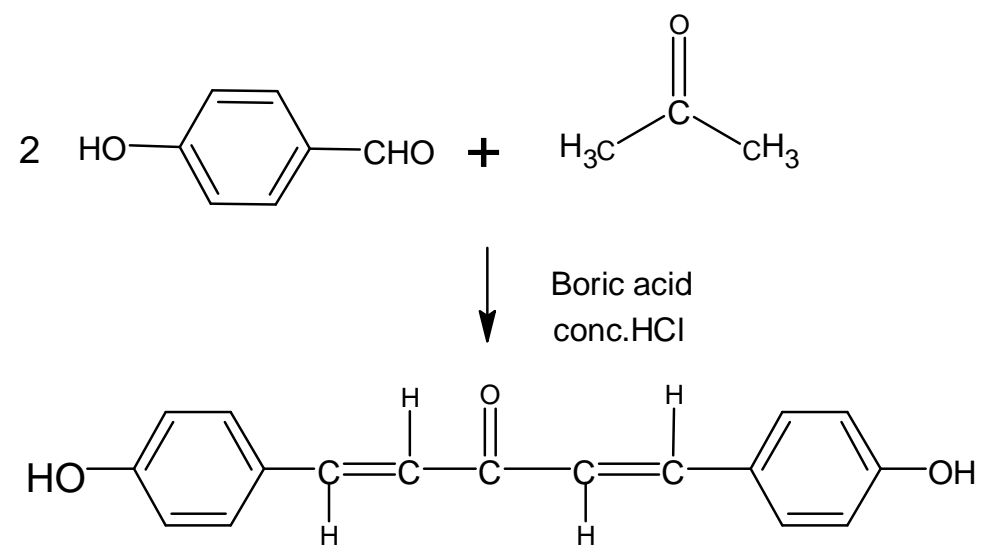

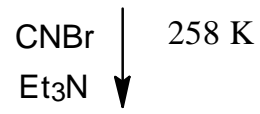

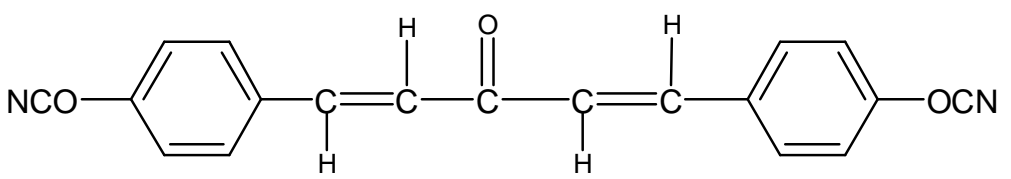

1,5-bis (4-cyanatophenyl)penta-1,4-dien-3-one

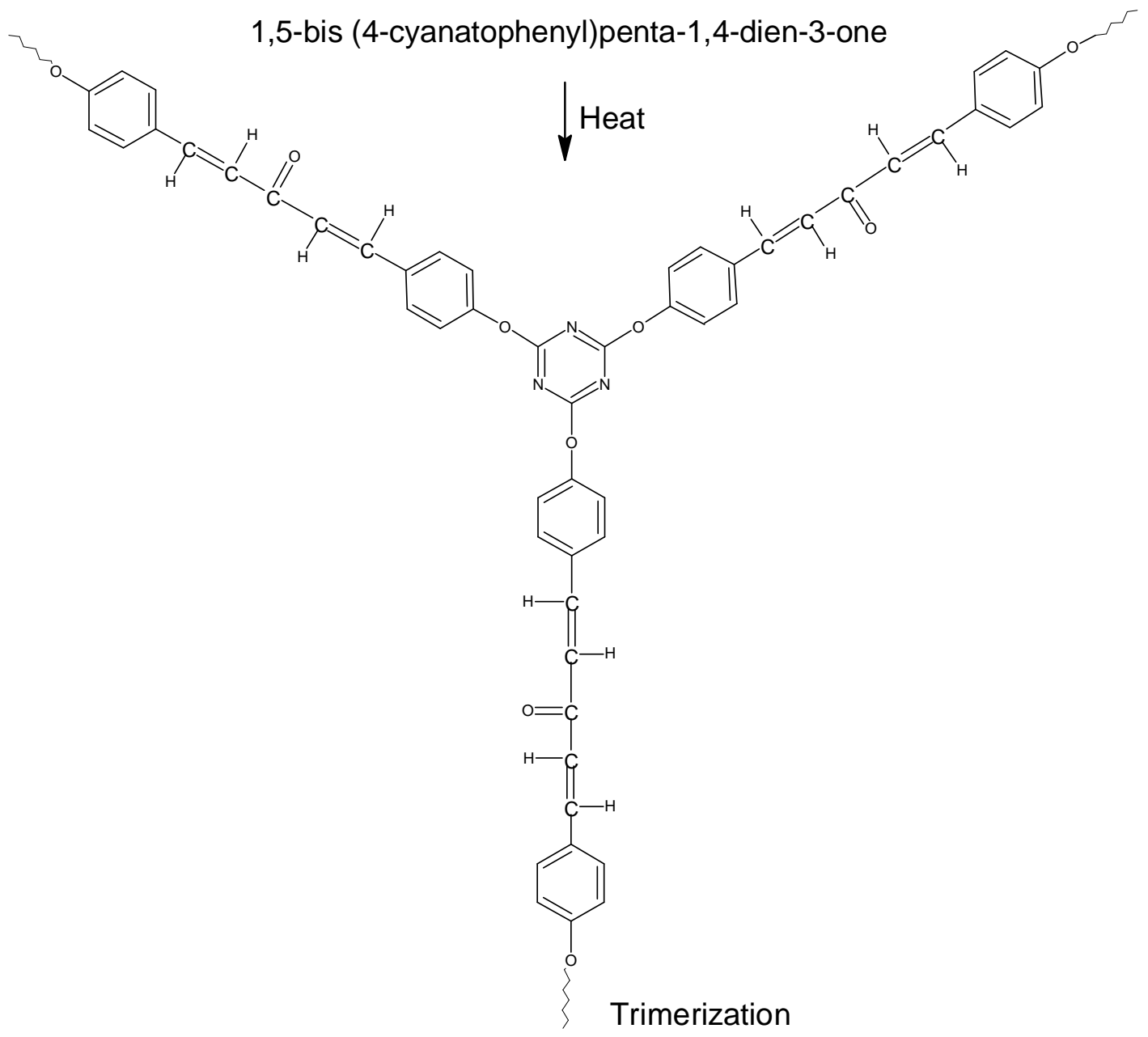

Scheme 1. Synthesis of cyanate ester (CPDO) 


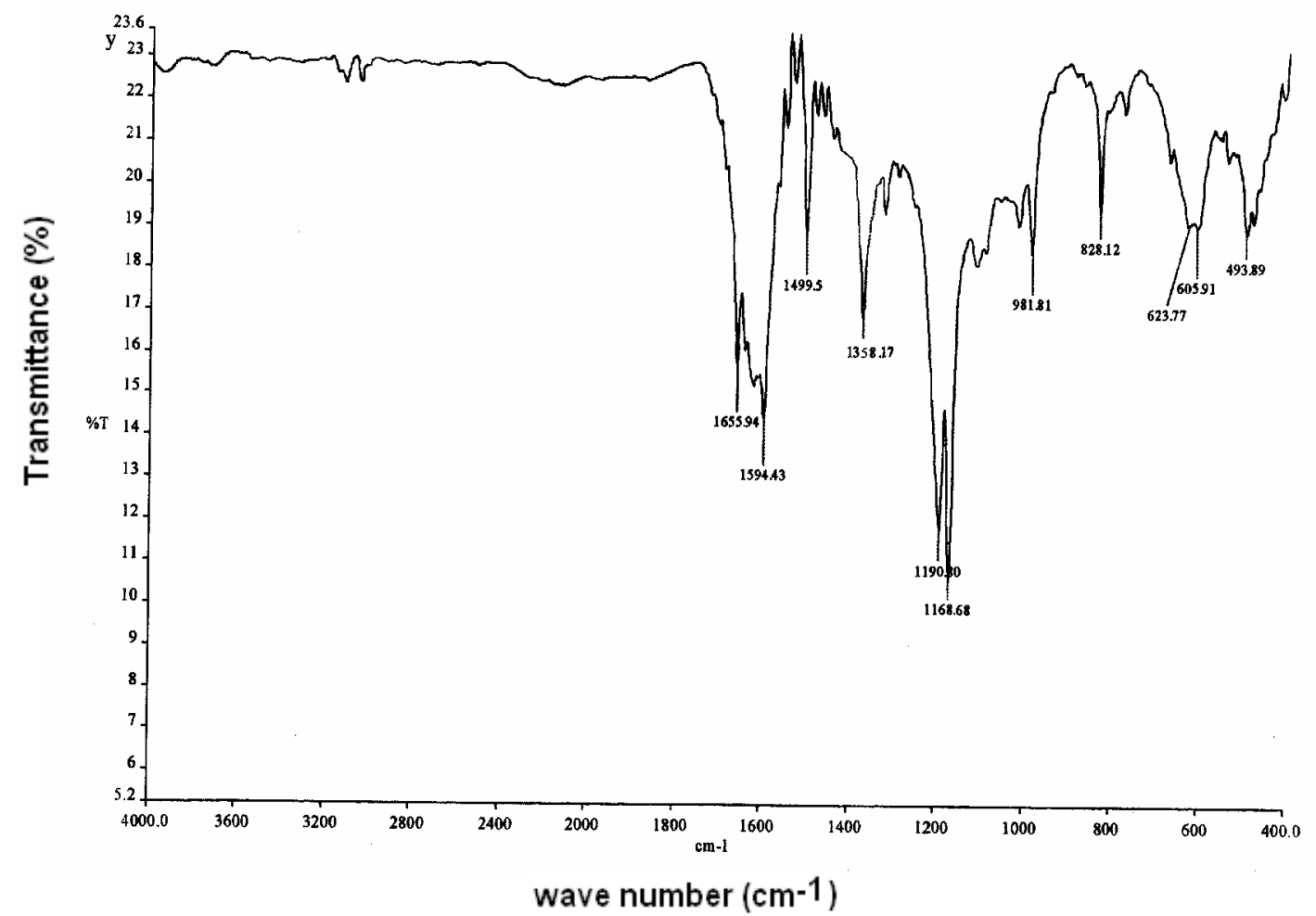

Fig. 3. FT-IR spectrum of cured CPDO

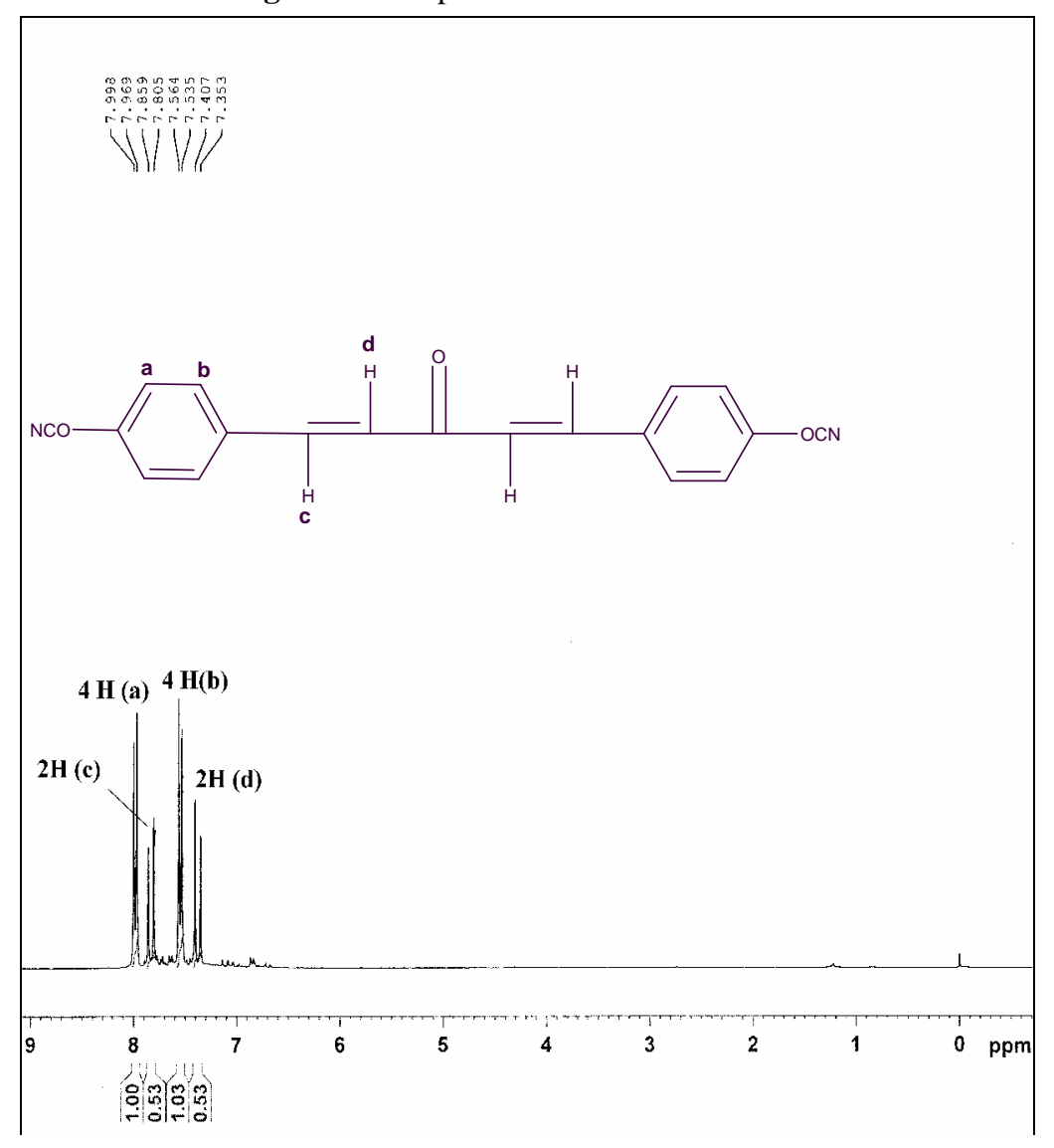

Fig. 4. ${ }^{1} \mathrm{H}-\mathrm{NMR}$ spectrum of CPDO 

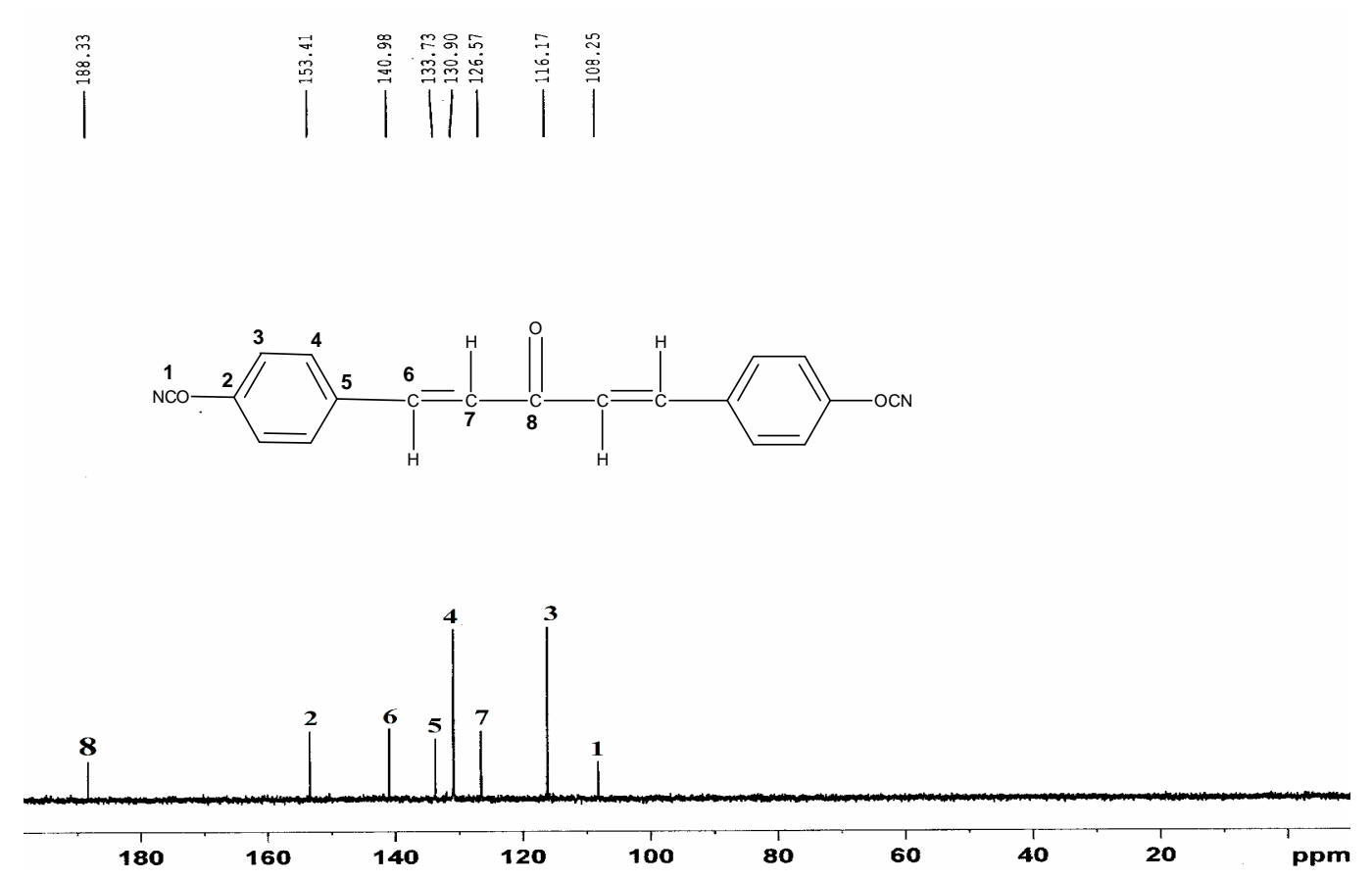

Fig. 5. ${ }^{13} \mathrm{C}-\mathrm{NMR}$ spectrum of CPDO

adjacent to aromatic ring appears at 140.98 ppm and $\mathrm{C}=\mathrm{C}$ carbon signal adjacent to the carbonyl group appears at $126.5 \mathrm{ppm}$. The signal at $188.33 \mathrm{ppm}$ corresponds to the carbonyl carbon $(\mathrm{C}=\mathrm{O})$. The calculated and experimental values of elemental analysis data are in good agreement. Hence, the proposed structure of the dicyanate ester is confirmed.

\subsection{DSC Analysis}

DSC analysis was carried out to study the cure behaviours of CPDO with and without a catalyst, BADCy and its blends (without a catalyst) respectively, at a heating rate of $283 \mathrm{~K} \cdot \mathrm{min}^{-1}$ (Fig. 6). Samples for the DSC analysis were prepared by the solution mixing at various ratios of CPDO with BADCy in dichloromethane and the solvent was evaporated. About $8 \mathrm{mg}$ of the dried sample was used for the analysis. The DSC thermogram of the CPDO monomer shows a typical sharp curing exotherm with a peak $\left(T_{p}\right)$ located at $466 \mathrm{~K}$ attributed to trimerization of the cyanate group. The endotherm that corresponds to the melting was observed at $444 \mathrm{~K}$. The initial curing temperature $\left(T_{i}\right)$ at $445 \mathrm{~K}$ indicates to an uncontrollable curing window [due to the simultaneous melting (at 444 $\mathrm{K}$ ) and onset of curing (at $445 \mathrm{~K}$ )]. In the case of BADCy, the melting of BADCy was observed as an endotherm at $357 \mathrm{~K}$ and it started curing at $496 \mathrm{~K}$ with the peak exotherm appearing at $548 \mathrm{~K}$, providing a controllable curing window. This controllable curing window implies the easiness/control over processing. The more the temperature gap between the initial and peak curing, the easier it is for keeping and curing the material at a low temperature with a good control over processing. But the higher initial cure temperature of $496 \mathrm{~K}$ outweighs the reasonable controllable curing window for BADCy. But in all blend compositions, the endotherm corresponding to the melting was observed around $347-357 \mathrm{~K}$. The blend ratios are shown in Table 1. While blending BADCy with CPDO, the $T_{i}$ got reduced to $414 \mathrm{~K}$ and the $T_{p}$ was shifted to a lower temperature of $456 \mathrm{~K}$. The processing of a thermosetting polymer is always carried out at or near the $T_{p}$. It is preferred to process a thermosetting polymer at lower temperatures to avoid void formation. If the polymer is processed at a higher temperature, due to a sudden increase in exothermicity (release of heat) hot spots can be formed. This eventually leads to the formation of voids. As far as the processing is concerned, the peak curing temperature is the primary concern. In this respect, the processing of BADCy was improved significantly by blending with CPDO. The $T$ of the blend decreased to $456-504 \mathrm{~K}$ in comparison to that of BADCy $(548 \mathrm{~K})$. Moreover, the final cure temperature $\left(T_{e}\right)$ of the blend was found to be in the range of 493-549 $\mathrm{K}$ compared to that of BADCy $(593 \mathrm{~K})$. BADCy has a wide cure window, the melting point of BADCy is $357 \mathrm{~K}$. But its cure initiation appears at a very high temperature of $496.5 \mathrm{~K}$. On the other hand CPDO has a lower cure temperature (444 K). However it has a high melting point. Hence, the cure window is small. It can be seen from the results obtained after blending CPDO with BADCy at various ratios, the high cure initiation of BADCy decreases to 419 K. Further, the high melting point of CPDO also decreases to $348 \mathrm{~K}$. 


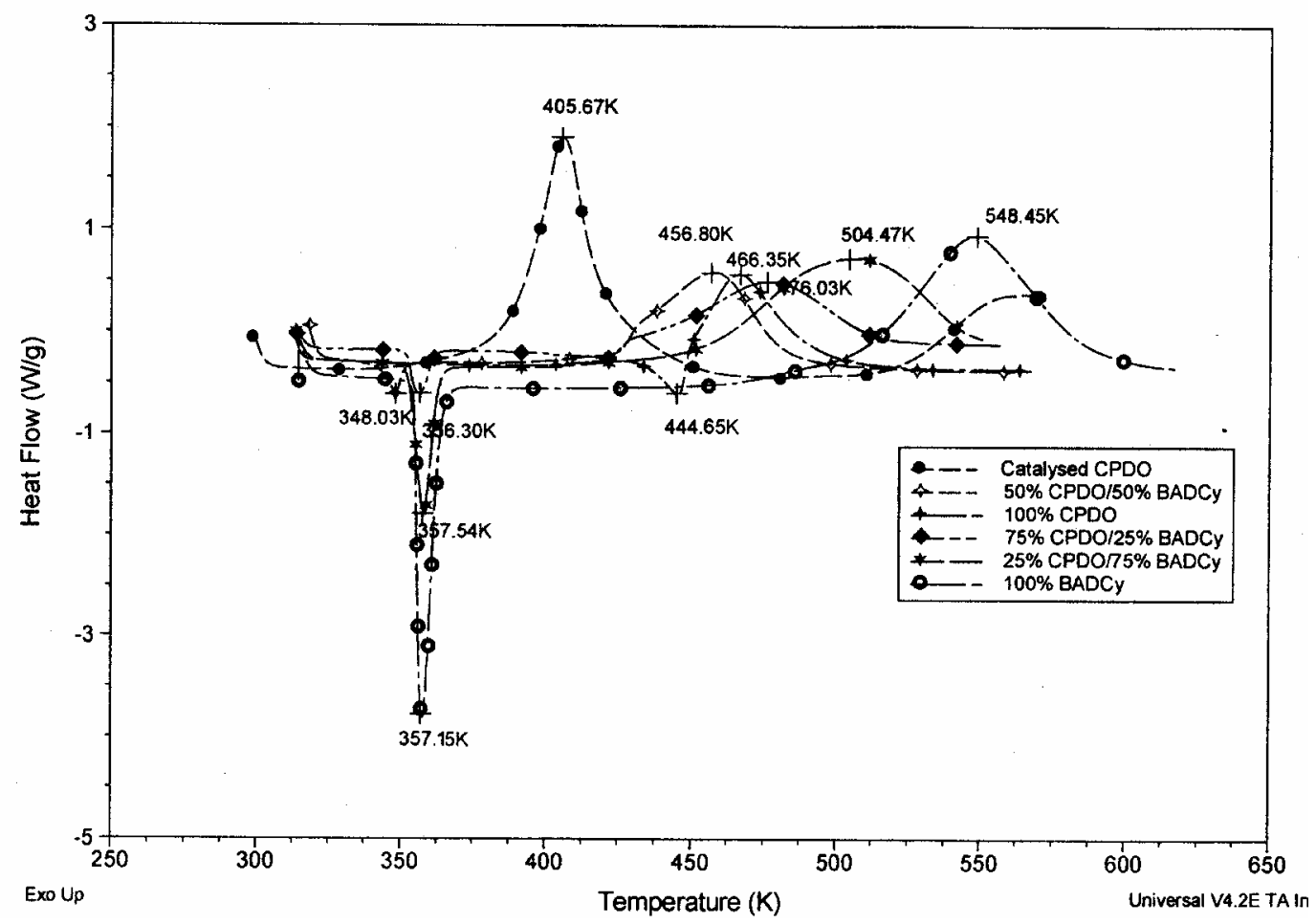

Fig. 6. DSC curves for CPDO, BADCy and CPDO/BADCy blends

DSC data for CPDO/BADCy blends

Table 1

\begin{tabular}{|c|c|c|c|}
\hline $\begin{array}{c}\text { Compositions with } \\
\text { CPDO:BADCy ratio, } \%\end{array}$ & $T_{i}, \mathrm{~K}$ & $T_{p,} \mathrm{~K}$ & $T_{e}, \mathrm{~K}$ \\
\hline $100: 0$ & 445 & 466.3 & 509.4 \\
\hline $75: 25$ & 420.1 & 476.1 & 521.7 \\
\hline $50: 50$ & 419.8 & 456.8 & 493.4 \\
\hline $25: 75$ & 450.2 & 504.4 & 549.6 \\
\hline $0: 100$ & 496.5 & 548.4 & 593.1 \\
\hline Catalysed CPDO & 347.6 & 405.5 & 463.5 \\
\hline
\end{tabular}

$T_{i}$ - initial cure temperature; $T_{p}$ - cure peak temperature; $T_{e}$ - end peak temperature; Cobalt naphthenate and nonyl phenol (mass ratio is $4: 25: 100$ ) is a catalyst.

TGA data for CPDO/BADCy blends

\begin{tabular}{|c|c|c|c|c|c|}
\hline $\begin{array}{c}\text { Composition with } \\
\text { CPDO:BADCy } \\
\text { ratio, } \%\end{array}$ & Sample code & $T_{o}, \mathrm{~K}$ & $T_{10}, \mathrm{~K}$ & $\begin{array}{c}\text { Char yield, } \\
\%\end{array}$ & LOI value \\
\hline $100: 0$ & $\mathrm{a}$ & 701.1 & 702.7 & 68 & 44.7 \\
\hline $75: 25$ & $\mathrm{~b}$ & 702.0 & 703.4 & 66 & 43.9 \\
\hline $50: 50$ & $\mathrm{c}$ & 703.5 & 704.3 & 62 & 42.3 \\
\hline $25: 75$ & $\mathrm{~d}$ & 704.3 & 705.1 & 58 & 40.7 \\
\hline $0: 100$ & $\mathrm{e}$ & 705.4 & 706.0 & 55 & 39.5 \\
\hline
\end{tabular}

$T_{o}$ - onset decomposition temperature; $T_{10}-10 \%$ weight loss temperature; $L O I$-limiting oxygen index

Table 2 
Thus, the controllable cure window can be achieved after blending these two cyanate esters. From the BADCy point of view, the processing characteristics of the blend are improved. Hence, by making a blend of these resins, the initial and peak curing temperatures are lowered in comparison to BADCy resins or in other words, the processing is facilitated. When CPDO was cured with the catalyst (cobalt naphthenate catalyst and nonylpnenol as a cocatalyst in weight percent ratio 4:25) the peak temperature was found to be shifted to a still further lower value (from $466 \mathrm{~K}$ to $405 \mathrm{~K}$ ), than for the neat CPDO.

\subsection{Thermogravimetric Analysis}

Thermogravimetric analysis (TGA) is the most favoured technique for the rapid evaluation of the thermal stability of polymeric materials. It is especially useful in comparing the thermal stabilities of various polymers. The relative thermal stability of cured aryl dicyanate esters was compared with the temperature of $10 \%$ weight loss $\left(T_{10}\right)$ and percentage of char yield at $1073 \mathrm{~K}$. This prepared dicyanate ester was then blended with a commercial bisphenol-A dicyanate ester (BADCy) at different ratios $(100: 0,75: 25,50: 50.25: 75,0: 100)$ and cured. The cured blends of different compositions of the present study were subjected to TGA in a nitrogen atmosphere and themograms are shown in Fig. 7. It can be seen from TGA that all formulations are stable towards heat in nitrogen up to temperatures greater than $673 \mathrm{~K}$, and may be used for elevated temperature service applications [16]. The TGA data for cured resins at various ratios of $\mathrm{CPDO} /$ BADCy are listed in Table 1. The cured resins of CPDO/
BADCy at various ratios exhibited $10 \%$ weight loss temperature $\left(T_{10}\right)$ ranging between $702-709 \mathrm{~K}$ in nitrogen and the anaerobic char yields at $1073 \mathrm{~K}$ ranging between 55-68\%. The thermal stability of cured resins slightly increases with the increase of BADCy content, which may occur due to the higher crosslink density compared to CPDO. It can be also observed that the char residue of formulations is increased and a thermal stability is decreased slightly with increasing CPDO content in the blend (704.3-702.0 K). Among the prepared cyanate ester blends, the initial degradation temperature is comparatively lower for CPDO. This may be due to more aliphatic linkages in CPDO compared to blend systems and neat BADCy network.

The char yield at $1073 \mathrm{~K}$ shows some variations according to different blend ratios. The flame retardancy of the cured cyanate ester resins was evaluated from their limiting oxygen index ( $L O I)$ value. The $L O I$ values of the polymer systems should be above the threshold value of 26 , to render self-extinguishing value and for their qualification in many applications requiring good flame resistance [17]. The $L O I$ value was calculated by using Krevelen's equation [18].

$$
L O I=17.5+0.4 \sigma
$$

where $\sigma$ is the percentage of a char yield. $L O I$ was found to be in the range of 39.5-44.7. The char formation at the polymer surface reduces flammability by acting as a barrier (principally carbonaceous) to inhibit gaseous products from diffusing to the flame and to shield the polymer surface. Thus, the developed cyanurate can be considered as a better flame retardant material.

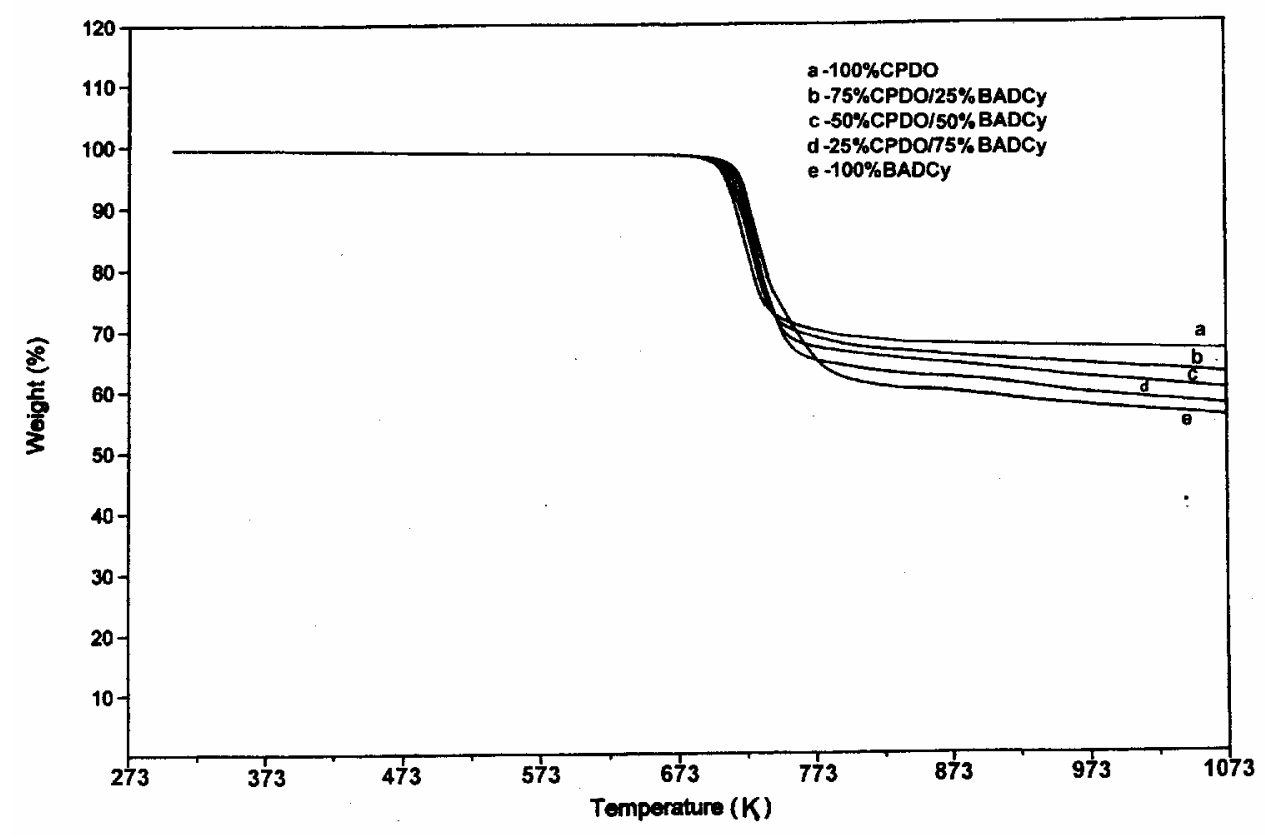

Fig. 7. Thermogram of CPDO, BADCy and CPDO/BADCy blends 


\section{Conclusions}

The present article deals with investigations of synthesis, characterization, curing and thermal properties of blends of CPDO with BADCy resin. CPDO/BADCy blend manifested an apparent single cure profile. BADCy cure was accelerated by CPDO. Thus, the processing temperature was lowered after blending. The thermal stability of the blends was significantly improved over that of CPDO. The results showed that the blending resulted in easier processing and marginal decrease in a thermal stability compared to BADCy.

\section{Acknowledgement}

The authors wish to thank University Grants Commission (UGC), New Delhi, India for their financial support.

\section{References}

[1] Fang T. and Shimp D.: Prog. Polym. Sci., 1995, 61.

[2] Fan J., Hu X. and Yue C.: J. Polym. Sci, Part B. Polym. Phys., 2003, 41, 1123.

[3] Herr D., Nikolic N. and Schultz R.: High Perform. Polym., 2001, 13, 79 .

[4] Hamerton I. and Hay J.: Polym. Inter., 1998, 47, 465.

[5] Hamerton I. and Hay J.: High Perform. Polym., 1998, 10,163.

[6] Shimp D. and Chin B.: Chem. \& Techn. Cyanate Ester Resins, 1994, 230.

[7] Nair C., Mathew D. and Ninan K.: Adv. Polym. Sci., 2001, 155, 1 .

[8] Hamerton I.: Chemistry and technology of cyanate ester. Chapman \& Hall, London 1994.

[9] Rath S., Boey F. and Abadie M.: Polym. Int., 2004, 53, 857.
[10] Bao J., Li Y. and Chen X.: Chinese J. Polym. Sci., 2001, 19, 53. [11] Zainol I., Day R. and Heatley F.: J. Appl. Polym. Sci., 2003, 90, 2764.

[12] Gu A., Liang G., Lan L. and Zheng X.: J. Northwestern Polytechn. Univ., 1996, 14, 163.

[13] Glauser T. and Johansson M.: Polymer, 1999, 40, 5297.

[14] Gaku M.: Polym. Mater. Sci. Eng., 1994, 71, 621.

[15] Mathew D., Reghunadhan Nair C. and Ninan K.: Polym. Int., 2000, 49, 48.

[16] Reghunadhan Nair C., Mathew D. and Ninan K.: Adv. Polym. Sci., 2001, 155, 1.

[17] Van Krevelen D.: Polymer, 1975, 16, 615.

[18] Borden D.: J. Appl.Polym.Sci., 1978, 22, 239.

\section{СИНТЕЗ І ХАРАКТЕРИСТИКА ЕСТЕРУ ЦАНАТУ ТА ЙОГО СУМШШЕЙ З БІСФЕНОЛЬНИМ ЕСТЕРОМ ДЩЦАНАТУ}

Анотація. На основі п-гідроксибензальдегіду і ацеетону, з використанням борної кислоти як каталізатора, отриманий новий функиіональний кето-ен 1,5-біс (4-гідроксифеніл) пента1,4-дієн-3-он. Одержаний бісфенол внаслідок його реакиії 3 иіананідом брому (CNBr) у присутності триетиламіну перетворено в 1,5-біс (4-ціанато-феніл) пента-1,4-дієн-3-он (ЦФД). Структура синтезованих продуктів підтверджена Фур'є-спектроскопією, ядерним магнітним резонансом та елементним аналізом. Приготовлено суміші ЦФД $з$ промисловим бісфенольним естером діціанату при різних співвідношеннях компонентів (100:0, 75:25, 50:50, 25:75, 0:100) та вивчені їх структуруючі характеристики за різних умов. Термічні властивості структурованих сумішей вивчені диферениійною скануючою калориметрією та з використанням термогравіметричного аналізу.

Ключові слова: естер ціанату, структурування при низькій температурі, термічні властивості. 